\title{
MODELLING OF ALLOMETRIC EQUATIONS FOR BIOMASS ESTIMATE IN DECIDUOUS FOREST
}

\author{
Rafaelo Balbinot ${ }^{1}$, Jonathan William Trautenmüller ${ }^{2 *}$, Braulio Otomar Caron ${ }^{1}$, Fábio Marcelo Breunig ${ }^{1}$, \\ Juliane Borella ${ }^{2}$, Renata Reis Carvalho ${ }^{2}$ \\ ${ }^{1}$ Universidade Federal de Santa Maria, Frederico Westphalen, Rio Grande do Sul, Brasil. rafaelo.balbinot@ gmail.com; \\ otomarcaron@yahoo.com.br; fabiobreunig@gmail.com \\ ${ }^{2}$ Universidade Federal do Paraná, Curitiba, Paraná, Brasil. jwtraute@ gmail.com*; borella.juli@gmail.com; renatacarvalho88@gmail.com
}

Received for publication: 19/03/2018 - Accepted for publication: 11/06/2018

\begin{abstract}
This paper aimed to test and adjust allometric models to estimate biomass in a Deciduous Forest. The data were obtained from seven $12 \times 12 \mathrm{~m}$ plots, from which 91 trees were cut down. Only trees with diameter at breast height $(\mathrm{DBH})$ greater than $5 \mathrm{~cm}$ were measured, and the fitting of the models was performed based on the $\mathrm{DBH}$, total height $(\mathrm{H})$ and total dry biomass (DAB) for each individual tree. The adjusted equations with no stratification presented adjusted determination coefficients $\left(\mathrm{R}^{2}{ }_{\text {aj }}\right)$ ranging from 0.726 to 0.972 and standard errors in percentage $\left(\mathrm{S}_{\mathrm{yx}} \%\right)$ from 33.5 to 119.6. The best adjusted model for nonstratified dataset was obtained by the Stepwise procedure, leading to the equation: $\mathrm{DAB}=\beta_{0}+\beta_{1}$. $\left(\mathrm{DBH}^{3}\right)$ $+\beta_{2} . \mathrm{H}+\beta_{3} .\left(\mathrm{DBH}^{3} . \mathrm{H}\right)$, with 0.954 of $\mathrm{R}^{2}$ aj and 44.0 of $\mathrm{S}_{\mathrm{yx}} \%$. For stratified dataset, only the diameter class higher than $15 \mathrm{~cm}$ presented acceptable results, with 0.968 of $\mathrm{R}^{2}$ aj and 26.5 of $\mathrm{S}_{\mathrm{yx}} \%$. The current database has shown good quality measurements for fitting stochastic models to estimate the biomass of each tree. Keywords: Carbon sequestration, allometric equations, trees biomass.
\end{abstract}

\section{Resumo}

Modelagem de equações alométricas para estimativa de biomassa em Floresta Estacional Decidual. O presente trabalho teve por objetivo ajustar e testar modelos alométricos para estimar biomassa em Floresta Estacional Decidual. Os dados são provenientes de sete parcelas de 12 x $12 \mathrm{~m}$, das quais foram abatidas 91 árvores com diâmetro à altura do peito (DAP) maior que $5 \mathrm{~cm}$, tendo sido mensurados o DAP, altura total $(\mathrm{H})$ e biomassa total (DAB) para cada indivíduo. As equações ajustadas sem estratificação apresentam coeficiente de determinação ajustado $\left(\mathrm{R}^{2}{ }_{\text {aj }}\right)$ entre 0,726 à 0,972 e erro padrão da estimativa em porcentagem $\left(\mathrm{S}_{\mathrm{yx}} \%\right)$ variando de 33,5 a 119,6 . O melhor modelo ajustado para o conjunto de dados não estratificados foi obtido por meio do procedimento Stepwise, cuja equação é: $\mathrm{DAB}=\beta_{0}+\beta_{1}$. (DAP $\left.{ }^{3}\right)+$ $\beta_{2} . \mathrm{H}+\beta_{3}$. $\left(\mathrm{DAP}^{3} . \mathrm{H}\right)$, com $\mathrm{R}^{2}$ aj de 0,954 e $\mathrm{S}_{\mathrm{yx}} \%$ de 44,0 . Para a forma estratificada, apenas a classe de diâmetro acima de $15 \mathrm{~cm}$ apresentou resultados aceitáveis, com $\mathrm{R}^{2}$ aj de 0,968 e $\mathrm{S}_{\mathrm{yx}} \%$ de 26,5. Diante disto, este banco de dados demostrou possuir medições que proporcionaram bons resultados nos ajustes de modelos estocásticos para estimar a biomassa das árvores.

Palavras-chave: Sequestro de carbono, equações alométricas, biomassa de árvores.

\section{INTRODUCTION}

The Brazilian Ministry of the Environment has been implementing the National Forest Inventory (IFN) through the Brazilian Forestry Service. Research programs are associated to the IFN as an important strategy in relation to the demand of studies that aim to estimate the forest biomass above soil. Information on the amount of forest biomass helps us to understand the accumulation of energy in forest ecosystems. In addition, it serves as an ecological indicator of sustainability (ABOAL et al., 2005). Reliable data on the forest biomass above soil are useful for the implementation of projects of the Reducing Emissions from Deforestation and Forest Degradation (REDD) (AVITABILE et al., 2011; CORTE et al., 2012), which was recently introduced in the Kyoto Protocol. These estimates help to evaluate the productivity of the forests and the sequestration and storage of carbon in different forest parts, such as trunk, branches and leaves (NÁVAR, 2009).

Quantification of biomass can be done directly or indirectly. The direct method involves cutting down trees to determine their exact weight and measurements (BALBINOT et al., 2009; SVOB et al., 2014).

FLORESTA, Curitiba, PR, v. 49, n. 1, p. 143-154, jan/mar 2019.

Balbinot. R. et.al.

ISSN eletrônico 1982-4688

143

DOI: $10.5380 /$ rf.v49 i1.58490 
This procedure is indispensable for a first acquaintance of the characteristics of the species. However, as soon as a significant number of determinations is obtained, we can resort to indirect methods, such as regression models. By using these methods, it is possible to cover larger ranges of forest areas and significantly reduce the magnitude of financial resources required for the work (BALBINOT et al., 2009).

For their application on local forests, simple models may only be used when the diameter at breast height $(\mathrm{DBH})$ exists. When applied, they are the best practical option to estimate the biomass (BASUKI et al., 2009). In regional scale, models based only on DBH may have a higher degree of uncertainty than more complex models. The estimate of the biomass of trees can be enhanced by the inclusion of the total height of the tress (NOGUEIRA et al., 2008).

Therefore, this study aimed to fit and test models traditionally used to estimate the individual volume of trees, as well as fit allometric equations to estimate aboveground biomass in Deciduous Forest.

\section{MATERIAL AND METHODS}

This study was developed in two fragments of Deciduous Forest (FED) (IBGE, 2012), located at the municipalities of Frederico Westphalen $\left(27^{\circ} 23^{\prime} 44^{\prime \prime} \mathrm{S}\right.$ and $53^{\circ} 25^{\prime} 59^{\prime \prime} \mathrm{W}$, altitude of 520 to 550 m.s.n.m.)

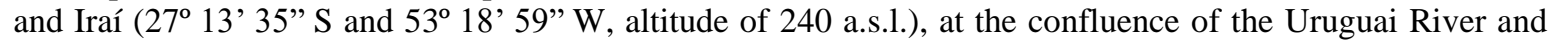
Várzea River. All collection and processing of data was performed through the months of January and March 2011 (Frederico Westphalen, state of Rio Grande do Sul, Brazil) and from May to July 2012 (Iraí, state of Rio Grande do Sul, Brazil).

The climate of the region is very humid subtropical, with a balanced rainfall system. However, there is a rainfall reduction during the winter season, with an annual average between 1,700 and 1,900 mm, and an average temperature between 20 and $23{ }^{\circ} \mathrm{C}$ (ROSSATO, 2014). The soil types of Frederico Westphalen and Iraí are classified as Aluminoferric Oxisol and Regolitic Eutrophic Neosol, respectively (SANTOS et al., 2013).

Seven 12 x $12 \mathrm{~m}\left(144 \mathrm{~m}^{2}\right)$ plots were installed, and all trees with the Diameter at Breast Height $(\mathrm{DBH}) \geq 5 \mathrm{~cm}$ were cut down. Then, the following variables were collected: $\mathrm{DBH}$, total height $(\mathrm{H})$ and total of dry aboveground biomass (DAB). These components were weighted by using the Lider PR-30 dynamometer, with capacity for $500 \mathrm{~kg}$ (minimum $1 \mathrm{~kg}$, error $\pm 100 \mathrm{~g}$ ). All samples of green material were weighted in a precision scale $(0.001 \mathrm{~g})$ at the end of the shift and put in a greenhouse with air circulation and renewal at $60{ }^{\circ} \mathrm{C}$ until they reached their constant weight. This procedure was carried out at the Forest Products Technology Laboratory (Federal University of Santa Maria - Campus Frederico Westphalen).

Stratification of the data into diameter classes was based on the fitting of a probability density function. Weibull function with three parameters was chosen to be fitted since it presents good adjustments for diameter distribution (ARAÚJO JÚNIOR et al., 2012; ORELLANA et al., 2014) (Equation 1).

$$
f(x)=\frac{\alpha}{\beta} *\left(\frac{x-\gamma}{\beta}\right)^{\alpha-1} * e^{\left[-\left(\frac{x-\gamma}{\beta}\right)^{\alpha}\right]}
$$

In which: $f(x)$ : probability density function of the variable $x ; \alpha, \beta, \gamma$ : parameters of the model to be estimated; $x$ : value of the random variable (diametric class center); and $e$ : constant of Euler $(2.7182 \ldots)$.

To define the number of diameter classes, Sturges method was used (Equation 2).

$$
K=1+3,33 *(\log n)
$$

In which: $K$ : class number; and $n$ : tree number.

The quality of the fitting of the functions was determined by the Kolmogorov-Smirnov (KS) test (Equation 3).

$$
\text { Deal }=\frac{\operatorname{maximun}\left[F_{0}(x)-F e(x)\right]}{n}
$$

In which: $F o(x)$ : observed frequency accumulated; $F e(x)$ : expected cumulative frequency; $n$ : tree number; and $D_{c a l}$ : D-value calculated by the Kolmogorov-Smirnov (KS) test.

FLORESTA, Curitiba, PR, v. 49, n. 1, p. 143-154, jan/mar 2019. 
In order to verify if the test was significant, the $\mathrm{D}_{\text {cal }}$ calculated was compared to the $\mathrm{D}_{\mathrm{tab}}$, tabulated, which is a tabulated value at the probability level of 5\% of significance (Equation 4).

$$
D_{\text {tab }}=\frac{1,96}{\sqrt{n}}
$$

In which: $D_{\text {tab }}$ : Kolmogorov-Smirnov tabled; and $n$ : tree number.

The allometric models were fitted for the entire database as well as for data grouped into two diametric classes. Based on the data on biomass, total height, and diameter, nine allometric models were fitted and tested. The adjusted models were Berkhout (1920), Kopezky-Gehrhardt (1899), Spurr (1952), Meyer (1938), Modified Meyer (1938), Modified Naslund (1947), Stoate (1945), and Hohenald-Krenn (1944), fitted by a Stepwise procedure. These models were selected because they are the most traditional volumetric equations in the forest management area.

The data were analyzed by the package Statistical Analysis System (SAS, 1993). Initially, the Stepwise procedure of regression modeling was applied by using the ordinary least squares method. For this procedure, the model followed Equation 5.

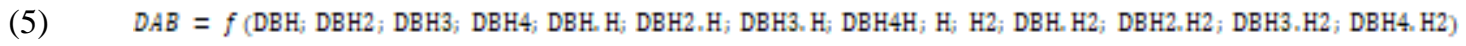

In which: DAB: dry aboveground biomass in $\mathrm{kg}$; $\mathrm{DBH}$ : diameter at breast height in $\mathrm{cm}$; and $\mathrm{H}$ : total height in $\mathrm{m}$.

In a second moment, the regression procedure (PROC MODEL in SAS) was performed. The homoscedasticity of the models was tested by the White (1980) test. If the model presented heteroscedasticity it was adjusted by the generalized least squares weighted (Equation 6).

$$
\hat{\beta}=\left(X^{f} \Psi(\hat{\theta})^{-1} X\right)^{-1} X^{t} \Psi(\hat{\theta})^{-1} y
$$

In which: $\Psi(\hat{\theta})$ : diagonal matrix of weights that depends on the number of parameters $(P)$ denoted by the vector $\mathrm{O}$ of the order $(P \cdot 1)$.

The best model was selected based on the adjusted determination coefficient $\left(\mathrm{R}_{\mathrm{aj}}{ }_{\mathrm{aj}}\right)$, estimate standard error in percentage ( $\left.S_{\mathrm{yx}} \%\right)$. The significance of the regression coefficients $\left(\beta o, \beta_{1}, \beta_{2}, \beta_{3}, \beta_{4}\right.$, and $\left.\beta_{5}\right)$ was tested by the $t$ test, and the graphic analysis of the distribution of the waste was calculated with the estimated values represented graphically according to the height of each individual.

\section{RESULTS}

A total of 91 trees was sampled, and four individuals were removed from the data set - two for presenting a broken canopy and two for their great part of the hollow bole. Therefore, 87 individuals were used, which belonged to 36 different species. Sorocea bonplandii (11), Trichilia claussenii (9), Nectandra megapotamica (6), and Inga marginata (5) were the species with the largest number of individuals.

There was a wide range of DAB among the trees, from 5.2 to $5471.1 \mathrm{~kg}$. Descriptive statistics show a standard deviation of $674.9 \mathrm{~kg}$, standard error of $72.4 \mathrm{~kg}$ and variance of $455,525.9 \mathrm{~kg}$ (Table 1).

Table 1. Descriptive statistics for 89 trees sampled and two diameter classes in a Deciduous Forest (FED).

Tabela 1. Estatísticas descritivas para as 89 árvores amostradas e duas classes de diâmetro em Floresta Estacional Decidual (FED).

\begin{tabular}{llll}
\hline Complete Data Set & & & \\
\hline \multirow{2}{*}{ Statistics } & Variable & & Biomass $(\mathbf{k g})$ \\
\cline { 2 - 4 } & H $(\mathbf{m})$ & DBH $(\mathbf{c m})$ & 5.2 \\
Minimum & 5.1 & 5.0 & 293.7 \\
Mean & 11.9 & 17.8 & 5471.1 \\
Maximum & 27.4 & 79.3 & \\
\hline
\end{tabular}

FLORESTA, Curitiba, PR, v. 49, n. 1, p. 143-154, jan/mar 2019.

Balbinot. R. et.al.

ISSN eletrônico 1982-4688

DOI: $10.5380 /$ rf.v49 i1.58490 


\begin{tabular}{llll}
\hline Standard deviation & 5.3 & 12.9 & 674.9 \\
Standard error & 0.6 & 1.4 & 72.4 \\
Variance & 28.5 & 166.0 & $455,525.9$ \\
\hline Class 1 (5 to 15 cm diameter at breast height) & & \\
\hline Minimum & 5.1 & 5.0 & 5.2 \\
Mean & 8.4 & 9.6 & 33.1 \\
Maximum & 19.2 & 14.7 & 134.0 \\
Standard deviation & 2.6 & 2.8 & 27.8 \\
Standard error & 0.4 & 0.4 & 4.0 \\
Variance & 6.9 & 8.2 & 773.3 \\
\hline Class 2 (more than $\mathbf{1 5}$ cm diameter at breast height) & & 50.7 \\
Minimum & 6.0 & 15.6 & 599.8 \\
Mean & 16.0 & 27.9 & $5,471.1$ \\
Maximum & 27.4 & 79.3 & 908.6 \\
Standard deviation & 4.7 & 12.7 & 143.7 \\
Standard error & 0.7 & 2.0 & $825,643.7$ \\
Variance & 22.6 & 162.2 & \\
\hline
\end{tabular}

It was observed that the adjusted equations with no stratification presented $\mathrm{R}_{\text {aj }}^{2}$ between 0.726 and 0.972 and $\mathrm{S}_{\mathrm{yx}} \%$ ranging from 33.5 to 119.6 . The White test was significant, demonstrating the lack of homoscedasticity for all the adjusted models (Table 2). The adjusted model that was considered appropriate to estimate the biomass of the trees with no stratification was obtained through the Stepwise procedure (9) (Table 2) (Equation 7), which presented lower $\mathrm{S}_{\mathrm{yx}} \%$ (33.5) and greater $\mathrm{R}_{\text {aj }}^{2}(0.972)$, whose equation coefficients were significant at $95 \%$ probability by the $t$ test.

$$
\mathrm{DAB}=\beta 0+\beta 1 \cdot(\mathrm{DBH} 3)+\beta 2 \cdot(\mathrm{H})+\beta 3 \cdot(\mathrm{DBH} 3 \cdot \mathrm{H})
$$

Meyer (4), Naslund modified (6), and Hohenald-Gehrhardt (8) models presented statistics of 0.968 , 0.969, 0.960 for $\mathrm{R}_{\mathrm{aj}}^{2}$, and 41.0, 39.9, 40.5 for $\mathrm{S}_{\mathrm{yx}} \%$, respectively. These results may have occurred due to the diversity of species and uneven-aged stands. Only model (9) was adjusted by the least squares weighted method for both the total set and the stratified ones.

Table 2. Estimates of parameters and statistics of the equations adjusted and tested for estimated tree biomass aboveground in a Deciduous Forest.

Tabela 2. Estimativa dos parâmetros e estatísticas das equações ajustadas e testadas para a estimativa da biomassa das árvores acima do solo na Floresta Estacional Decidual.

\begin{tabular}{|c|c|c|c|c|c|c|c|c|c|}
\hline \multirow[t]{3}{*}{ No. } & \multicolumn{9}{|c|}{ Parameters Estimates } \\
\hline & \multicolumn{9}{|c|}{ Ordinary Least Squares } \\
\hline & $\boldsymbol{\beta}_{\mathbf{0}}$ & $\beta_{1}$ & $\boldsymbol{\beta}_{2}$ & $\boldsymbol{\beta}_{3}$ & $\beta_{4}$ & $\beta_{5}$ & $\mathbf{R}_{\text {aj }}$ & $\mathrm{S}_{\mathrm{yx}} \%$ & White \\
\hline 1 & $-501.056^{*}$ & $44.730 *$ & - & - & - & - & 0.726 & 119.6 & $70.50^{*}$ \\
\hline 2 & $-78.895^{*}$ & $0.776^{*}$ & - & - & - & - & 0.943 & 54.7 & $47.52 *$ \\
\hline 3 & $9.697 \mathrm{~ns}$ & $0.033^{*}$ & - & - & - & - & 0.953 & 49.4 & $48.51^{*}$ \\
\hline 4 & $-196.649^{*}$ & $-6.764 n s$ & $0.954 *$ & $-1.872 *$ & $0.017 \mathrm{~ns}$ & $41.967^{*}$ & 0.968 & 41.0 & $70.82 *$ \\
\hline 5 & $83.764 \mathrm{~ns}$ & $-10.718 \mathrm{~ns}$ & $0.647 \mathrm{~ns}$ & $-0.009 \mathrm{~ns}$ & $0.015 \mathrm{~ns}$ & - & 0.959 & 46.1 & $72.48 *$ \\
\hline 6 & $-74.934 *$ & $0.107 \mathrm{~ns}$ & $0.056^{*}$ & $-0.103^{*}$ & $1.793^{*}$ & - & 0.969 & 39.9 & $69.25 *$ \\
\hline 7 & $48.751 \mathrm{~ns}$ & $-6.204 n s$ & $0.215 \mathrm{~ns}$ & $0.025^{*}$ & - & - & 0.954 & 49.0 & $64.32 *$ \\
\hline 8 & $126.964^{*}$ & $-18.780 *$ & $1.043^{*}$ & - & - & - & 0.960 & 40.5 & $34.95^{*}$ \\
\hline 9 & $-112.131 *$ & $0.016^{*}$ & $16.716^{*}$ & $-0.00023^{*}$ & - & - & 0.972 & 33.5 & $61.68^{*}$ \\
\hline \multicolumn{10}{|c|}{ Generalized Least Squares Weighted } \\
\hline 9 & $-32.5607^{*}$ & $0.022835^{*}$ & $6.063571^{*}$ & $-0.00044 *$ & - & - & 0.954 & 44.0 & $5.33 \mathrm{~ns}$ \\
\hline
\end{tabular}

$\mathrm{R}_{\mathrm{aj}}{ }_{\mathrm{aj}}$ : adjusted determination coefficient; $\mathrm{S}_{\mathrm{yx}} \%$ : estimate standard error in percentage; ns: did not present statistic difference by the $\mathrm{t}$ test and White test at a level 5\% of error probability; and *: presented statistic difference by the t test and White test at a level 5\% of error probability.

FLORESTA, Curitiba, PR, v. 49, n. 1, p. 143-154, jan/mar 2019.

Balbinot. R. et.al. 
Through the analysis of waste distribution, it was verified that all models presented a similar tendency. Individuals with greater diameters for the non-stratified data set presented greater error (Figure 1). Figure 2A shows the distribution of the weighted waste. For the stratified data, the Weibull distribution with three parameters, which was adhered by the KS test (calculated $=0.0108$, and tabulated $=0.1458$ ) and not significant at $5 \%$ of probability, was used (Figure 3). This result indicates that the frequencies estimated and observed do not differ statistically in essential aspects for the null hypothesis.
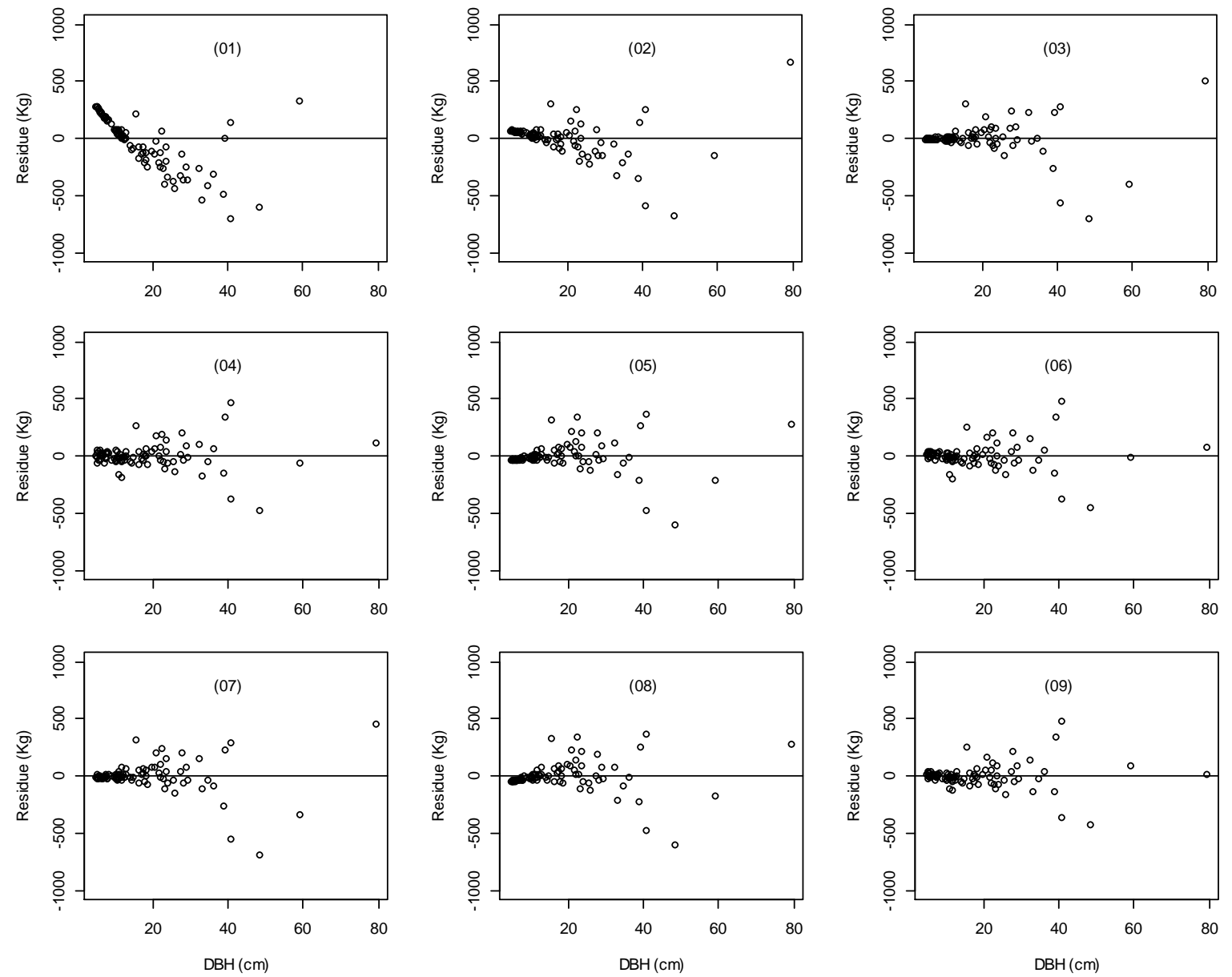

Figure 1. Distribution of the waste of the estimates on biomass according to the diameter at breast height (DBH).

Figura 1. Distribuição dos resíduos das estimativas de biomassa em função do diâmetro à altura do peito $(\mathrm{DBH})$. 

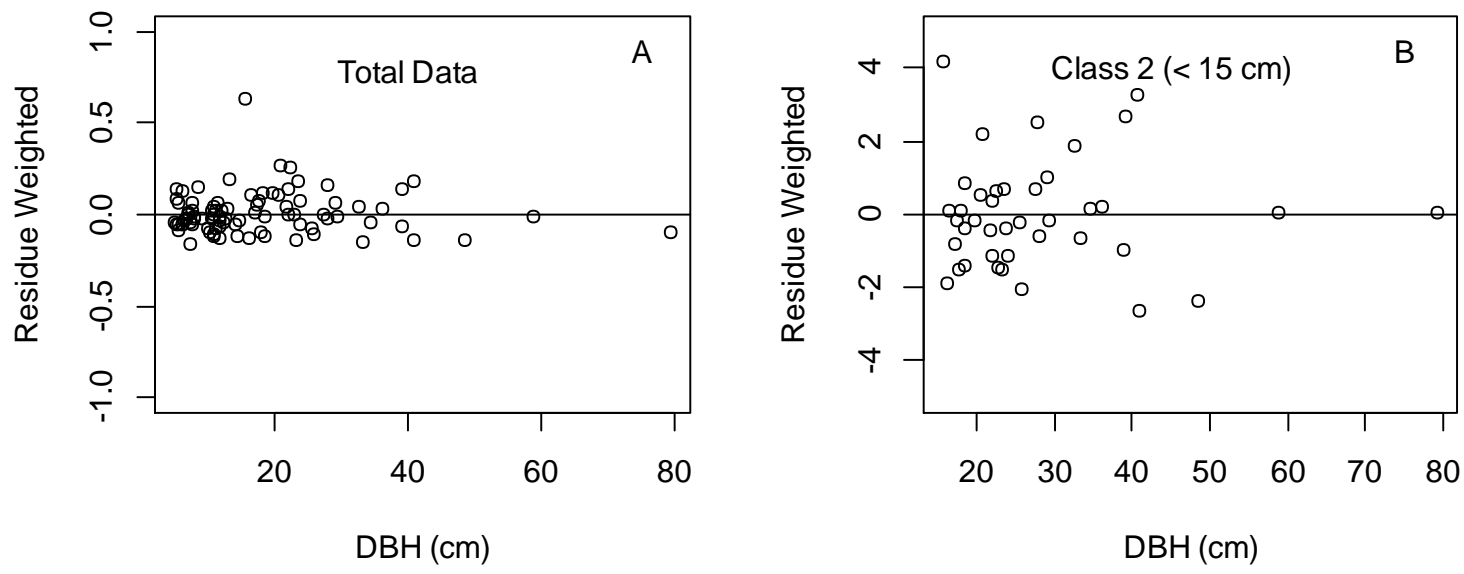

Figure 2. Distribution of the waste of the estimates on biomass according to the diameter at breast height (DBH) with correction of heteroscedasticity for the total data (A) and the diameter class $<15 \mathrm{~cm}$ (B).

Figura 2. Distribuição dos resíduos das estimativas de biomassa em função do diâmetro na altura do peito (DBH) com correção da heterocedasticidade para o conjunto total dos dados (A) e para a classe de diâmetro $<15 \mathrm{~cm}(\mathrm{~B})$.

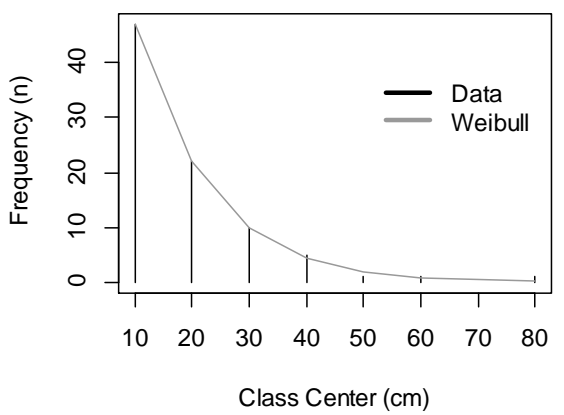

Figure 3. Observed frequency and Weibull function curve tested for the distribution of forest diameters.

Figura 3. Frequência observada e curva da função Weibull ajustada para a distribuição dos diâmetros da floresta.

Stratification of the data resulted into two diameter classes. The first class (class 1) included all tress with DBH between 5 and $15 \mathrm{~cm}$ (47 trees), and the second class (class2) included all trees with DBH higher than $15 \mathrm{~cm}$ (40). Both classes had more than 30 trees per class. The fitting allometric equations for trees stratified into the diameter classes generated better results for class 2 (Table 3). However, for each diameter class, an equation was obtained for comparison to the non-stratified equation.

Table 3. Estimates of parameters and statistics of the equations fitted and tested to estimate the aboveground biomass by diameter classes in a Deciduous Forest.

Tabela 3. Estimativas dos Parâmetros e estatísticas das equações ajustadas e testadas para a estimativa de biomassa acima do solo nas duas classes de diâmetro na Floresta Estacional Decidual. 


\begin{tabular}{|c|c|c|c|c|c|c|c|c|c|c|}
\hline \multirow{3}{*}{$\begin{array}{c}\begin{array}{c}\text { Diameter } \\
\text { class }\end{array} \\
\end{array}$} & \multirow[t]{3}{*}{ No. } & \multicolumn{9}{|c|}{ Parameters Estimates } \\
\hline & & \multicolumn{8}{|c|}{ Ordinary Least Squares } & \multirow[b]{2}{*}{ White } \\
\hline & & $\boldsymbol{\beta}_{\mathbf{0}}$ & $\beta_{1}$ & $\boldsymbol{\beta}_{2}$ & $\boldsymbol{\beta}_{3}$ & $\beta_{4}$ & $\beta_{5}$ & $\mathbf{R}^{2}{ }_{\text {aj }}$ & $S_{y x} \%$ & \\
\hline \multirow{9}{*}{$5-15 \mathrm{~cm}$} & 1 & $-34.846^{*}$ & $7.423^{*}$ & - & - & - & - & 0.572 & 54.3 & $3.32 \mathrm{~ns}$ \\
\hline & 2 & $-3.200^{\mathrm{ns}}$ & $0.396^{*}$ & - & - & - & - & 0.580 & 53.7 & $3.82 \mathrm{~ns}$ \\
\hline & 3 & $3.532^{\mathrm{ns}}$ & $0.035^{*}$ & - & - & - & - & 0.684 & 46.7 & $3.63 \mathrm{~ns}$ \\
\hline & 4 & $93.949^{\text {ns }}$ & $-23.795^{\mathrm{ns}}$ & $1.408^{\text {ns }}$ & $2.859^{\mathrm{ns}}$ & $-0.131^{\mathrm{ns}}$ & $-11.045^{\mathrm{ns}}$ & 0.659 & 48.4 & $10.38 \mathrm{~ns}$ \\
\hline & 5 & $-6.100^{\mathrm{ns}}$ & $2.070^{\text {ns }}$ & $-0.081^{\text {ns }}$ & $0.002^{\text {ns }}$ & $0.030^{\mathrm{ns}}$ & - & 0.662 & 48.2 & $17.04 \mathrm{~ns}$ \\
\hline & 6 & $-2.308^{\mathrm{ns}}$ & $0.119^{\text {ns }}$ & $0.022^{\text {ns }}$ & $-0.004^{\mathrm{ns}}$ & $0.114^{\mathrm{ns}}$ & - & 0.662 & 48.2 & $15.84 \mathrm{~ns}$ \\
\hline & 7 & $-8.010^{\mathrm{ns}}$ & $1.596^{\mathrm{ns}}$ & $0.093^{\text {ns }}$ & $0.022^{\mathrm{ns}}$ & - & - & 0.671 & 47.6 & $6.33 \mathrm{~ns}$ \\
\hline & 8 & $-6.0731^{\mathrm{ns}}$ & $0.663^{\mathrm{ns}}$ & $0.361^{\mathrm{ns}}$ & - & - & - & 0.571 & 54.3 & $4.38 \mathrm{~ns}$ \\
\hline & 9 & $-17.245^{*}$ & $0.0145^{*}$ & $3.8368^{*}$ & $0.0004^{\mathrm{ns}}$ & - & - & 0.782 & 38.7 & $5.67 \mathrm{~ns}$ \\
\hline \multirow{9}{*}{$>15 \mathrm{~cm}$} & 1 & $-1191.98^{*}$ & $64.263^{*}$ & - & - & - & - & 0.806 & 55.0 & $31.92 *$ \\
\hline & 2 & $-160.733^{*}$ & $0.813^{*}$ & - & - & - & - & 0.938 & 37.3 & $14.48 *$ \\
\hline & 3 & $17.240^{\mathrm{ns}}$ & $0.032 *$ & - & - & - & - & 0.942 & 35.8 & $21.56^{*}$ \\
\hline & 4 & $-246.08^{\mathrm{ns}}$ & $-18.187^{\mathrm{ns}}$ & $1.336^{\mathrm{ns}}$ & $-2.404^{\mathrm{ns}}$ & $0.0 .11^{\mathrm{ns}}$ & $66.471^{\mathrm{ns}}$ & 0.965 & 27.9 & $28.47 *$ \\
\hline & 5 & $1054.19 *$ & $-98.860 *$ & $3.216^{*}$ & $0.067^{\mathrm{ns}}$ & $-0.073^{\text {ns }}$ & - & 0.962 & 29.1 & $32.84 *$ \\
\hline & 6 & $-137.231^{\mathrm{ns}}$ & $0.092^{\mathrm{ns}}$ & $0.064^{*}$ & $-0.137 *$ & $2.677 *$ & - & 0.966 & 27.5 & $28.12 *$ \\
\hline & 7 & $203.223^{\mathrm{ns}}$ & $-14.019^{\mathrm{ns}}$ & $0.050^{\mathrm{ns}}$ & $0.032 *$ & - & - & 0.943 & 35.6 & $33.70 *$ \\
\hline & 8 & $577.956^{*}$ & $-42.864 *$ & $1.301 *$ & - & - & - & 0.960 & 29.9 & $18.31 *$ \\
\hline & 9 & $-69.194^{\mathrm{ns}}$ & $0.010 *$ & $16.760 *$ & - & - & - & 0.968 & 26.8 & $28.45 *$ \\
\hline \multicolumn{11}{|c|}{ Weighted Least Squares } \\
\hline$>15 \mathrm{~cm}$ & 9 & -95.192 & 0.010255 & 18.34707 & - & - & - & 0.968 & 26.5 & $13.41 \mathrm{~ns}$ \\
\hline
\end{tabular}

$\mathrm{F}_{\text {cal }}$ : value of the $\mathrm{F}$ test calculated; $\mathrm{R}_{\mathrm{aj}}{ }_{\mathrm{aj}}$ : adjusted determination coefficient; $\mathrm{S}_{\mathrm{yx}} \%$ : estimate standard error in percentage; ${ }^{\mathrm{ns}}$ : did not present statistic difference by the $t$ test at a level $5 \%$ of error probability.

Once the fitted equations for each data set were selected (stratified and non-stratified), it was possible to compare the models. The adjusted equations for the diameter class between 5 and $15 \mathrm{~cm}$ of DBH presented inferior results (Figure 4). When compared to the diameter class higher than $15 \mathrm{~cm}$ of DBH with non-stratified form, the stratified forms presented lower $\mathrm{R}^{2}$ aj and better $\mathrm{S}_{\mathrm{yx}} \%$, from 26.8 to $29.1 \%$ (Figure 5). For the diameter class higher than $15 \mathrm{~cm}$ of $\mathrm{DBH}$, there was a presence of heteroscedasticity for all models tested. For this reason, the weighted fitted equation was the best. Figure 2B shows the distribution of waste for the weighted equation. 

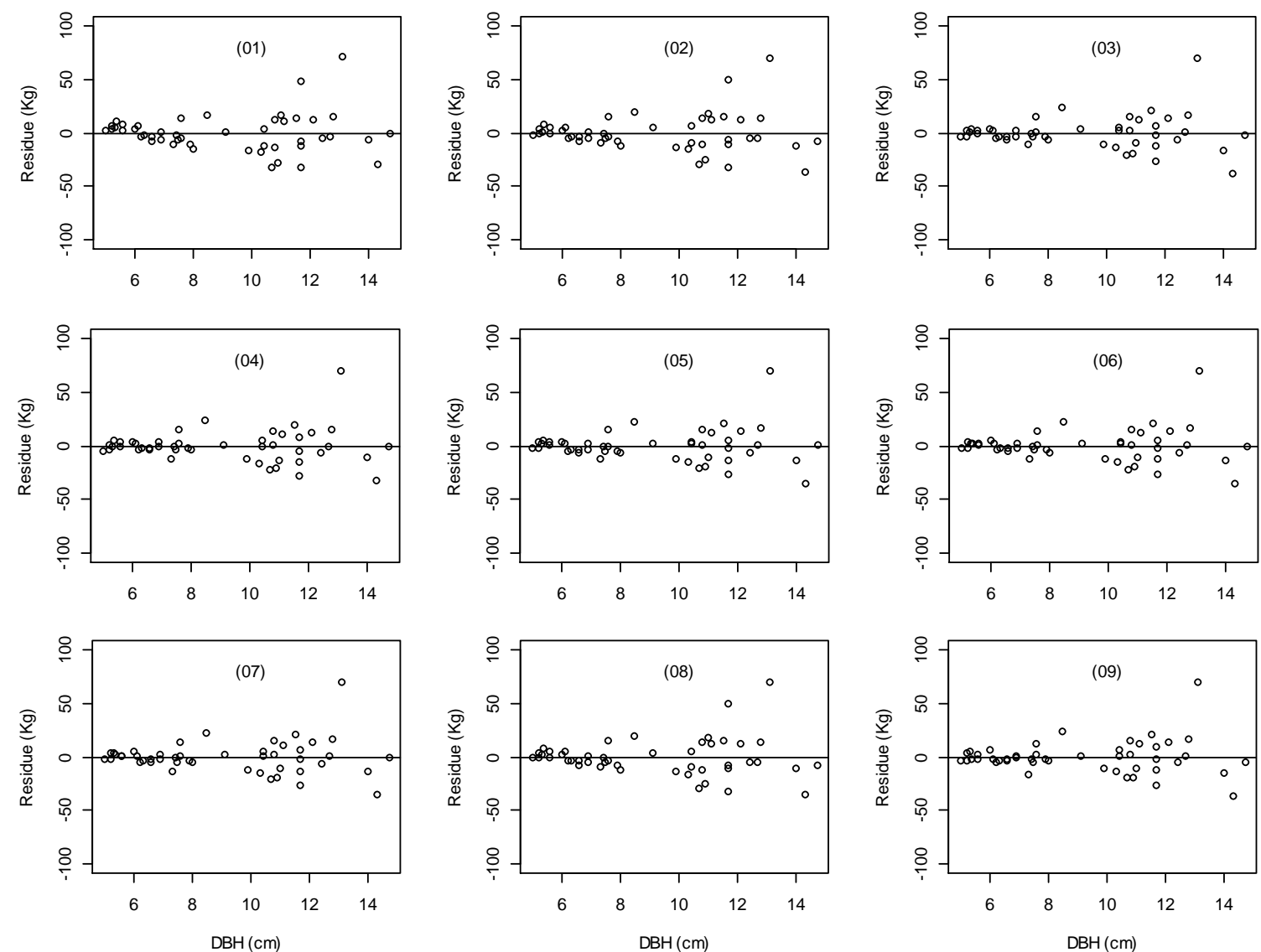

Figure 4. Distribution of the waste of the estimates on biomass according to the diameter at breast height (DBH) for the diameter class from 5 to $15 \mathrm{~cm}$.

Figura 4. Distribuição dos resíduos das estimativas de biomassa em função do diâmetro à altura do peito (DBH) para a classe de diâmetro de 5 a $15 \mathrm{~cm}$.
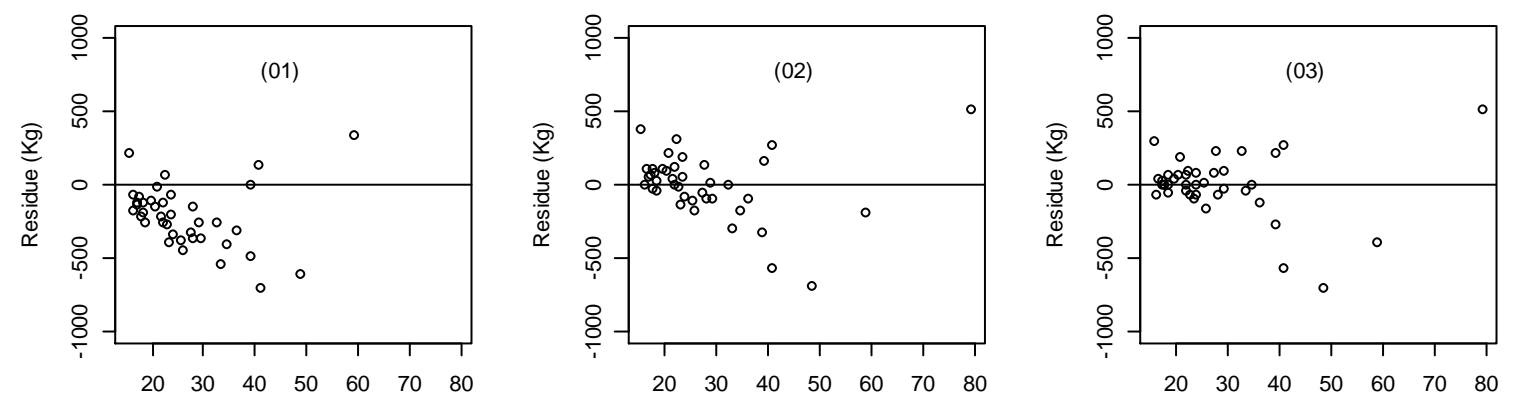

FLORESTA, Curitiba, PR, v. 49, n. 1, p. 143-154, jan/mar 2019.

Balbinot. R. et.al. 

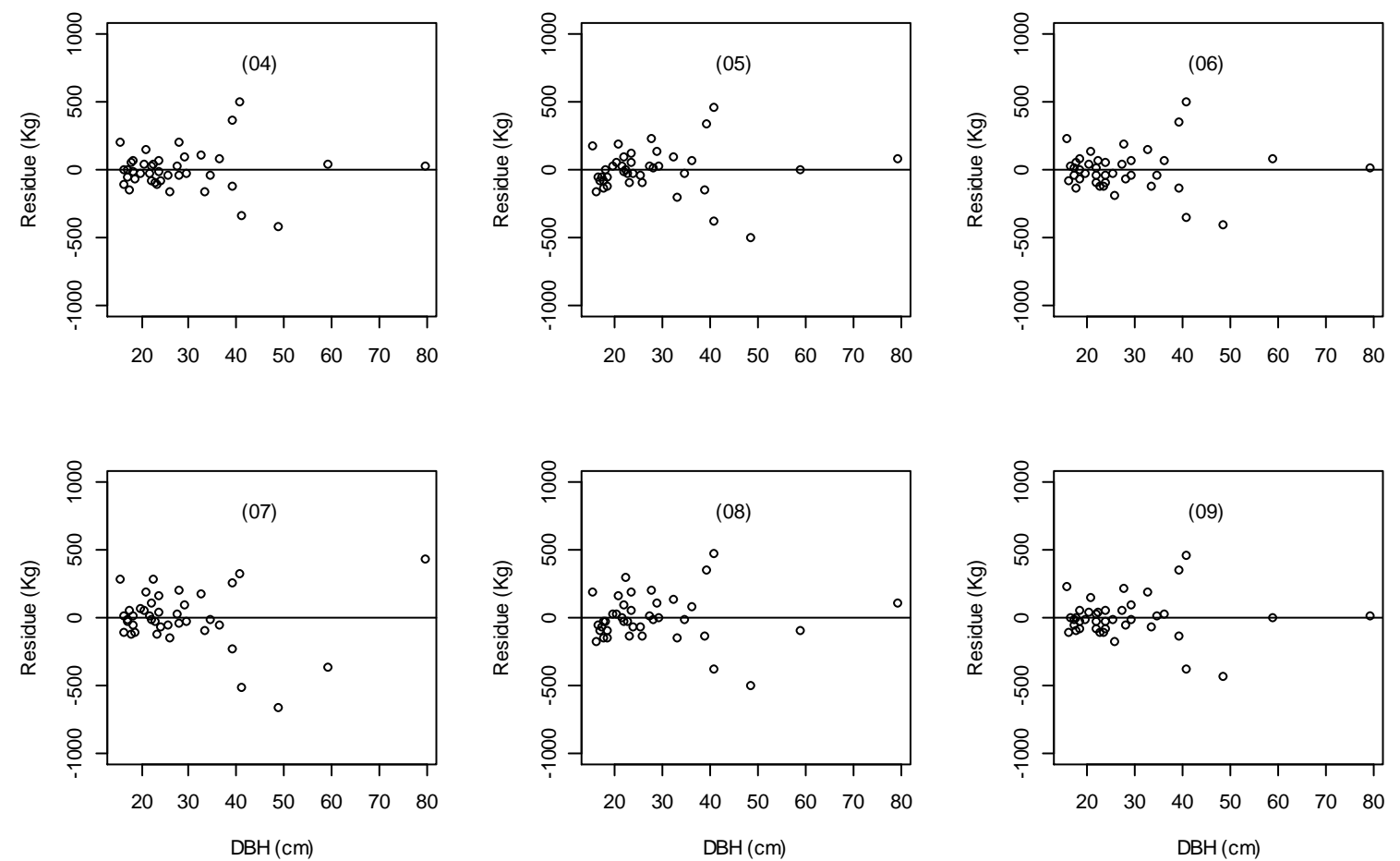

Figure 5. Distribution of the waste of the estimates on according to the diameter at breast height (DBH) for the diameter class higher than $15 \mathrm{~cm}$.

Figura 5. Distribuição dos resíduos das estimativas de biomassa em função do diâmetro à altura do peito (DBH) para a classe de diâmetro acima de $15 \mathrm{~cm}$.

\section{DISCUSSION}

In conditions in which all plants with $\mathrm{DBH} \geq 5 \mathrm{~cm}$ were considered, such as in the present study, errors are usually high (Table 1), mainly due to the variability of the tree architecture, as observed by Hálle (2010) and Costa et al. (2012). However, other aspects were identified, such as the occurrence of broken canopies and the presence of hollow boles or boles attacked by fungi that reduce the basic specific mass (weight) of the bole wood. Consequently, these aspects lead to the heteroscedasticity of the data, i.e, the error variance is not constant for all observations.

Meyer (4), Naslund modified (6), and Hohenald-Gehrhardt (8) equations showed $\mathrm{R}^{2}{ }_{\mathrm{aj}}$ and $\mathrm{S}_{\mathrm{yx}} \%$ of $40 \%$, and these results were accepted for uneven-aged stands. This may have occurred due to the lack of allometric correlation between the variables aboveground biomass with diameter and height. The lack of correlation mainly occurs when natural forests present a negative exponential diametric distribution (ARAÚJO et al., 2012).

Burger and Delitti (2008) found 0.94 of $\mathrm{R}_{\text {aj }}$ and $0.56 \mathrm{~kg}$ of standard error, using for the logarithm equation $\ln \mathrm{DAB}=-3.676+0.951 * \ln \left(\mathrm{DBH}^{2} \mathrm{H}\right)$, when they fitted simple regression analysis equations for a fragment of the Atlantic Forest. However, $S_{\mathrm{yx}}$ was not corrected by the Meyer Factor. Miranda et al. (2011) found coefficients of 0.918 of $\mathrm{R}_{\text {aj }}^{2}$ and $42.39 \%$ of $\mathrm{S}_{\mathrm{yx}} \%$ in reforested areas (44 species) with ages ranging from 5 to 36 years-old. Considering these results and the variation of the data used, the statistics can be considered satisfactory.

The independent variables for the four fitted equations use DBH and H. DBH presented more significance than $\mathrm{H}$, even though the inclusion of $\mathrm{H}$ improved the final statistics. Therefore, these models are generally better than the ones that use only the DBH. However, the measurement of $\mathrm{H}$ with precision and accuracy in native forests is difficult due to the overlay of canopies (CHAVE et al., 2005; BURGER; DELITTI, 2010; LIMA et al., 2012). In addition, this variable also has higher cost for measurement when compared to the DBH. When the wastes of models 7 and 8 are compared, their distribution is similar.

FLORESTA, Curitiba, PR, v. 49, n. 1, p. 143-154, jan/mar 2019.

Balbinot. R. et.al.

ISSN eletrônico 1982-4688

151

DOI: $10.5380 /$ rf.v49 i1.58490 
However, we need to consider that model 8 uses only the DBH and model 7 uses both the DBH and H. Thus, model 8 is recommended due to its smaller operational cost and greater accuracy for the measurement of the DBH.

In the stratified form, class 1 presented great variation of heights (Table 3). Thus, the allometric relation was not very strong, resulting in low coefficients of determination and high error patterns (CURTO $e t$ al., 2014). The application of the adjusted models with no stratification resulted in better adjustments by the stratification per diametric class. However, it is worth noting that there are no great differences between the general adjustment (with no stratification) and the stratified form. Therefore, the use of this stratification may be decided by the researcher according to the objectives of the research, since they can influence in the time of collection and processing of data, as well as in costs.

\section{CONCLUSIONS}

- Traditional models do not present a good fitting when compared to the Stepwise procedure, which generated the model PST $=\beta_{0}+\beta_{1} \cdot\left(\mathrm{DBH}^{3}\right)+\beta_{2} \cdot(\mathrm{H})+\beta_{3} \cdot\left(\mathrm{DBH}^{3} \cdot \mathrm{H}\right)$, and showed lower $\mathrm{S}_{\mathrm{xy}} \%$ (33.5) and higher $\mathrm{R}_{\text {aj }}^{2}(0.972)$.

- Non-stratification of the data presented better statistics for models fitting.

- The use of the generalized least squares weighted procedure enables the correction of the heteroscedasticity of the selected equation for both entire database and stratified databases.

\section{ACKNOWLEDGEMENTS}

The authors thank the financial support of the Research Support Foundation of the State of Rio Grande do Sul (FAPERGS), processes 10/0164-5 and 10/1818-5, to the Brazilian National Council for Scientific and Technological Development (CNPq), grant 309030/2017-0, and to the Brazilian Coordination for the Improvement of Higher Education Personnel (CAPES) for the master's scholarship to the lead author. Anonymous reviewer comments were appreciated.

\section{REFERENCE}

ABOAL, J. R., ARÉVALO, J. R., FERNÁNDEZ, Ä. Allometric relationships of different tree species and stand above ground biomass in the Gomera laurel forest (Canary Islands). Flora, v.200, p.264-274, 2005.

ARAÚJO, E. J. G.; PEliSSARI, A. L.; DAVID, H. C.; SCOLFORO, J. R. S.; PÉlliCO NETTO, S.; MORAIS, V. A. Relação hipsométrica para candeia (Eremanthus erythropappus) com diferentes espaçamentos de plantio em Minas Gerais, Brasil. Pesquisa Florestal Brasileira, Colombo, v. 32, n. 71, p. 257-268, 2012.

ARAÚJO JÚNIOR, C. A., LEITE, H. G., BINOTI, D. H. B., CASTRO, R. V. O., BINOTI, M. L. M. S., MARCATTI, G. E. Uso da função Weibull para descrever a área basal por classe de diâmetro de um povoamento de eucalipto. Scientia Forestalis, Piracicaba, 40, n.95, p.401-406, 2012.

AVITABILE, V.; HEROLD, M.; HERNRY, M.; SCHMULLIUS, C. Mapping biomass with remote sensing: a comparison of methods for the case study of Uganda. Carbon Balance and Management, Moscou, v. 6, n. 7, 2011.

BALBINOT, R.; KOEHLER, H. S.; WATZLAWICK, L. F.; MARCENE, E. A. Estoque de carbono em plantações de Pinus spp. em diferentes idades no sul do estado do Paraná. Floresta, Curitiba, v. 38, p. 317324, 2008.

BASUKI, T. M., VAN LAAKE, P. E., SKIDMORE, A. K., HUSSIN, Y. A. Allometric equations for estimating the above-ground biomass in tropical lowland Dipterocarp forests. Forest Ecology and Management, Amsterdam, v. 257, p. 1684-1694, 2009.

BURGER, D. M; DELITTI, W. B. C. Modelos preditores da fitomassa em floresta da restinga. Revista Brasileira de Botânica, São Paulo, v. 33, n. 1, p. 143-153, 2010. 
BURGER, D. M.; DELITTI, W. B. C. Allometric models for estimating the phytomass of a secondary Atlantic Forest area of southeastern Brazil. Biota Neotropica, v. 8, n. 4, p. 131-136, 2008.

CHAVE, J., ANDALO, C., BROWN, S., CAIRNS, M. A., CHAMBERS, J. Q., EAMUS, D., FOLSTER, H., FROMARD, F., HIGUCHI, N., KIRA, T., LESCURE, J. P., NELSON, B. W., OGAWA, H., PUIG, H., RIÉRA, B., YAMAKURA, T. Tree allometry and improved estimation of carbon stocks and balance in tropical forests. Oecologia, v. 145, p. 87-99, 2005.

CORTE, A. P. D.; SANQUETTA, C. R.; KIRCHNER, F. F.; ROSOT, N. C. Os projetos de redução de emissões do desmatamento e da degradação florestal (REDD). Floresta, Curitiba, v. 42, n. 1, p. 177-188, 2012.

COSTA, M. P.; PEREIRA, J. A. A.; BENICIO, M. H. M.; SOUZA, H.; FONTES, M. A. L.; GARCIA, P. O. Alometria e arquitetura de Copaifera langsdorffii (Desf.) Kuntze (Fabaceae) em fitofisionomias neotropicais no sul de Minas Gerais. Ciência Florestal, Santa Maria, v. 22, n. 2, p. 223-240, 2012.

CURTO, R. A.; LOUREIRO, G. H.; MÔRA, R.; MIRANDA, R.O.V.; NETTO, S. P.; SILVA, G. F. Relação hipsométrica em floresta estacional decidual. Revista de Ciências Agrárias, v. 57, n. 1, p. 57-66, 2014.

HALLÉ, F. Arquitectura de los árboles. Boletín de la Sociedad Argentina de Botánica, v.45, n.3-4, p.405418. 2010.

IBGE, INSTITUTO BRASILEIRO DE GEOGRAFIA E ESTATÍSTICA. Manual técnico da vegetação brasileira. Rio de Janeiro, 2. ed. rev. e ampl., 2012, 271 p.

LIMA, A. J. N.; SUWA, R.; RIBEIRO, G. H. P. M.; KAJIMOTO, T.; SANTOS, J.; SILVA, R. P.; SOUZA, C. A. S.; BARROS, P. C. DE; NOGUCHI, H.; ISHIZUKA, M.; HIGUCHI, N. Allometric models for estimating above- and below-ground biomass in Amazonian forests at São Gabriel da Cachoeira in the upper Rio Negro, Brazil. Forest Ecology and Management, Amsterdam, v. 277. p, 163-172. 2012.

MIRANDA, D. L.C.; MELO, A. C. G.; SANQUETTA, C. R. Equações alométricas para estimativas de biomassa e carbono em árvores de reflorestamento de restauração. Revista Árvore, Viçosa, v. 35, n. 3, p. 679-689, 2011.

NÁVAR, J. Allometric equations for tree species and carbon stocks for forests of northwestern Mexico. Forest Ecology and Management, Amsterdam, v. 257, p. 427-434, 2009.

NOGUEIRA, E. M., NELSON, B. W., FEARNSIDE, P. M., FRANCA, M. B., OLIVEIRA, A. C. A. D. Tree height in Brazil's "arc of deforestation": shorter trees in South and Southwest Amazonia imply lower biomass. Forest Ecology and Management, Amsterdam, v. 255, p. 2963-2972, 2008.

ORELLANA, E., FIGUEIREDO FILHO, A., PÉLLICO NETTO, S., DIAS, A. N. Modelagem da distribuição diamétrica de espécies florestais em um fragmento de Floresta Ombrófila Mista. Revista Árvore, Viçosa, v.38, n.2, p.297-308, 2014.

ROSSATO, M. S. Os climas do Rio Grande do Sul: Tendências e tipologias. In: Mendonça, F. (Org.). Os climas do Sul: Em tempos de mudanças climáticas globais. Jundiaí: Paco Editorial, 2014. p. 217-271.

SANTOS, H. G.; JACOMINE, P. K. T.; ANJOS, L. H. C.; OLIVEIRA, V. A.; LUBRERAS, J. F.; COELHO, M. R.; ALMEIDA, J. A.; CUNHA, T. J. F.; OLIVEIRA, J. B. Sistema Brasileiro de Classificação de Solos. 3. ed. Brasília, EMBRAPA, 353p, 2013.

SAS - STATISTICAL ANALYSIS SYSTEM: Programa de computador, ambiente VM. Cary, 1993. Versão 6.08 .

SVOB, S.; ARROYO-MORA, J. P.; KALACSKA, M. The development of a forestry geodatabase for natural forest management plans in Costa Rica. Forest Ecology and Management, Amsterdam, v. 327, p. 240-250, 2014.

FLORESTA, Curitiba, PR, v. 49, n. 1, p. 143-154, jan/mar 2019.

Balbinot. R. et.al.

ISSN eletrônico 1982-4688

DOI: $10.5380 /$ rf.v49 i1.58490 
FLORESTA, Curitiba, PR, v. 49, n. 1, p. 143-154, jan/mar 2019. Balbinot. R. et.al. 